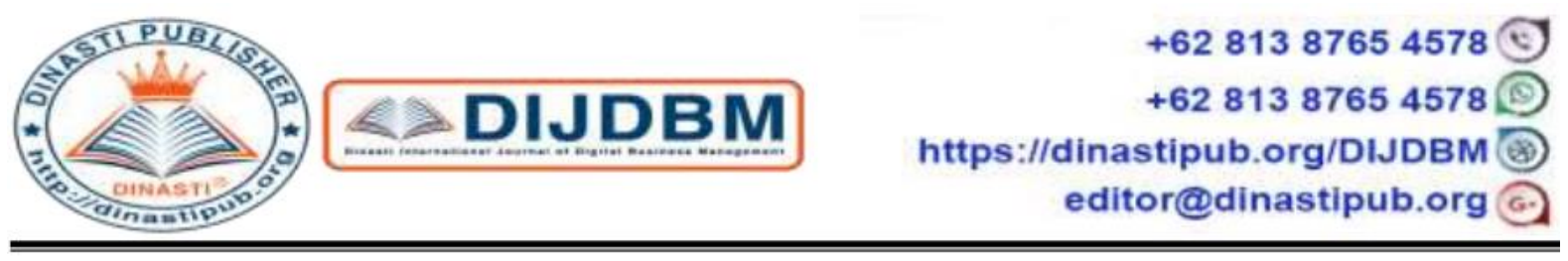

\title{
IMPLEMENTATION OF INFORMATION SYSTEM IN TRAVELOKA COMPANY
}

Tashya Amaraesty ${ }^{1)}$

${ }^{1)}$ Mercu Buana University, Jakarta, Indonesia

\begin{tabular}{|l|l|}
\hline $\begin{array}{c}\text { ARTICLE INFORMATION } \\
\text { Received: 3 January 2020 } \\
\text { Revised: 9 January 2020 } \\
\text { Issued: 13 January 2020 }\end{array}$ & $\begin{array}{l}\text { Abstract: The development of information } \\
\text { technology has changed the world to become easier } \\
\text { and bring development and progress in all fields. With } \\
\text { the support of computer technology it is proven that } \\
\text { the mechanism of long and repetitive work becomes } \\
\text { effective and efficient. Information systems play an } \\
\text { important role in supporting the smooth work } \\
\text { activities in an information, how to organize data with } \\
\text { a database system that has been supporting the } \\
\text { Tashya Amaresty } \\
\begin{array}{l}\text { E-mail: } \\
\text { amaraesty @gmail.com }\end{array}\end{array}$ \\
\hline $\begin{array}{l}\text { performance of many agencies. Writing Purpose This } \\
\text { would like to know how much influence an } \\
\text { information system is implemented in a company and } \\
\text { what are the strengths and weaknesses arising from } \\
\text { the application of an information system in a traveloka } \\
\text { company. This writing uses a qualitative method with } \\
\text { literauture studies in the field of Scientific } \\
\text { Information Systems and Information Technology } \\
\text { (IT). Information is obtained from the artiker, module } \\
\text { and the internet. Besides that, based on empirical } \\
\text { experience and direct observation on the object of } \\
\text { research. } \\
\text { Keywords: : Information System, Internal Control, } \\
\text { Traveloka }\end{array}$ \\
\hline
\end{tabular}

\section{INTRODUCTION}

Technological developments have changed the world more easily and brought development and progress in all fields. With the support of computer technology proven from long and repetitive work to be effective and efficient. The computer plays an important role in supporting the smooth work activities in an information, data method with a database system that has been supporting the support of many institutions.

Information is very important for management in making decisions, information can be obtained from information systems. The rapid development of information requires an institution to make changes in an existing system, because the problems involved are growing. 
Dependence on information systems in the modern era is something that is still shared by all groups. Utilization of technology for information systems began to be complicated for use by companies starting, this proves that multi-national class companies or fairly large companies only implement information systems.

One company that uses the information system is Traveloka, a traveloka company that uses smart phone technology based on Android or I-phone OS to serve in the field of travel services, wherever and wherever the information system supported by the organization or company provides assistance to customers or OS consumers. This information system is connected to a large network that is the internet making it easier for companies from customers or customers. With the internet the company has also been helped in expanding its reach.

This modern era puts selected technology as a tool for process automation so that it becomes an important factor in managing business strategies. Computer-based information management systems with business strategies are a diamond step to get a competitive advantage from success. But, of course there are advantages and benefits that can be received by the system, still in essence that exists as flaws and weaknesses in the system, which can occur due to internal and external factors. Weaknesses that can also occur due to Fraud that can be rejected modern information systems. For this reason, a company or institution requests an apprenticeship permit to minimize shortcomings and shortcomings of a system.

\section{LITERATURE REVIEW}

\section{Understanding the system}

The system is a collection of elements that are interrelated and work together for a particular purpose. Understanding the system according to Andri Kristanto (2008: 1) is a network of interrelated procedures, coordinating together to carry out various activities or complete certain targets. Another case according to Budi Sutedjo Dharma Oetomo (2006: 168), the system is a collection of elements that are interconnected with each other that form a unity in an effort to achieve goals. Meanwhile according to Jogiyanto (2005: 1), a system is a collection of elements - elements that integrate to achieve certain goals.

From the description above we can know about the system that compiles a collection of subsystems that have a specific purpose, where within the subsystem there are certain tasks to become a unity in achieving a goal. According Jogiyanto (2005: 4) the system has several characteristics as follows:

\section{Has Components (components)}

A system consists of several interconnected components, which are intended to work together to form a unity. System components or system elements can form a subsystem or parts of the system that have the properties of the system that make a particular system and affect the overall system process.

\section{Has a System Limit (limit)}

System boundary (boundary) is an area that is determined between the system with other systems or with the external environment. This system limit allows a system to choose a place. System space limits the scope of the system.

3. The existence of the environment outside the system 
Environment outside the system is anything that exceeds the limits of the system that improves the operating system.

\section{Having Connections}

Liaison is a media liaison between one subsystem with another subsystem, which uses resources - resources flow from one subsystem to another subsystem. By connecting one subsystem, it can integrate with other subsystems to form a single unit.

\section{Has input (input)}

Enter is the energy put into the system.

\section{Has Output (output)}

Output is the result of energy processed and classified into useful output and residual waste. Output can be input for other systems.

\section{Has a processor (process)}

A system can have a processing part or the system itself as the processor. Processor that will convert input into output.

\section{Having goals (objectives) or goals (goals)}

A system will definitely have a goal (goal) or target (objectives). If the system does not have a target, then the system operation will be of no use. The system goal is to determine the input needed by the system and the output produced by the system. The system can be said to be successful when it comes to goals and objectives.

\section{Understanding Information}

Information is one of the most important types of resources owned by an organization. Seeing the importance of the role of information, information needs to be managed well in order to help an organization to obtain quality information. According to Budi Sutedjo Dharma Oetomo (2006: 168) information is the result of processing data obtained from each element of the system into a form that is easily understood and is relevant knowledge needed by people separately to increase their understanding of the facts that exist. Meanwhile, according to Azhar Susanto (2004: 18) information is the result of data processing that gives meaning and benefits. From the above understanding it can be concluded that information is the result of data processing that gives meaning or meaning and is useful or beneficial for the recipient of the information. According to Gelinas in Azhar Susanto (2004: 41) expresses his opinion about the characteristics of an information. These characteristics are:

1. Effectiveness means information must be in accordance with the needs of users in supporting a business process, including information must be presented in the right time, the right format so that it can be understood, consistent with the previous format, the contents are in accordance with current needs and complete or in accordance with needs and conditions.

2. Efficiency means that information is produced through the optimal use of resources.

3. Confidential means to pay attention to protection or protection of sensitive information from unauthorized parties.

4. Integrity means that the information generated must be the result of integrated data processing based on applicable rules. 
5. Availability means that the information needed must always be available whenever needed. For this reason, security of information resources is needed.

6. Compliance means that the information generated must comply with laws or government regulations and have responsibilities both internal and external parties of the company's organization.

7. Truth means that information has been presented by the information system correctly and can be trusted so that it can be used by management to operate the company.

\section{Understanding Information Systems}

Information systems in a system include data entry (input) then processed through a model in data processing and information results will be captured again as an input and so on so as to form an information cycle that can be obtained from the information system as a special system in the organization to process the information. At a glance the information system can be interpreted as a combination of people, facilities or technological tools, media, procedures and control over certain activities that produce an information that can be utilized by the wearer. According to Budi Sutedjo Dharma Oetomo (2006: 11) information systems can be defined as a collection of elements that are interconnected with each other that form a single unit to integrate data, process and store and distribute information. Another case with Al-Bahra Bin Ladjamudin (2005: 13) information systems are defined as a set of organizational procedures that when implemented will provide information for decision makers and or for controlling information. Then we can conclude that the information system is a unity of elements that interact with each other systematically and orderly to create and shape the flow of information that supports decision making.

The information system activities are as follows:

1. Input, which describes an activity to provide data for the process.

2. Process, which describes how a data is processed to produce information that has added value.

3. Storage, which is an activity to maintain and store data.

4. Output, which is an activity to produce a report of an information process.

5. Control, which is an activity to ensure that the information system runs as expected.

While the information system components consist of:

1. Hardware (hardware), consisting of computers, printers, networks.

2. Software (software).

3. Data, is a basic component of information.

4. Human (user).

\section{Definition of Fraud}

Fraud includes various irregularities and illegal actions that are marked by intentional or wrong fraud. The Institute of Internal Auditors (IIA) defines fraud as:

"Any illegal action marked by deception, concealment, or breach of trust This action does not depend on the threat of violence or physical force. Fraud is committed by parties and organizations to obtain money, property or services; to avoid payment or loss of services; or to secure personal or business benefits. "

Another definition of cheating from the publication of the Practical Guide, which is sponsored by the American Institute of Certified Public Accountants, and the Certified Fraud Examiner Association, states: 
"Fraud is a deliberate act or omission that is designed to deceive others, resulting in victims suffering losses and / or perpetrators achieving profits."

common characteristics of cheating:

1. Pressure can come from the needs that must be met by individuals by committing fraud. Often, the pressure comes from significant finances, this problem may include the need to keep a job or get a bonus. Generally jobs have large targets or other financial rewards can be obtained based on meeting certain performance goals. The perpetrator has a desire to maintain his position in the organization and to maintain certain standards of life to compete with his peers. 2. Opportunity is the ability to commit fraud and not be detected because the perpetrators do not want to be caught in their actions, they have confidence that their activities will not be detected. Fraud opportunities exist because of weak internal control, poor management, lack of board oversight, and / or through the use of one's position and authority to override control. Failure to establish adequate procedures for detecting fraudulent activity also increases the chances of fraud occurring. A process might be designed correctly for typical conditions, however, a window of opportunity might arise creating a state so that control fails.

\section{Internal control}

Internal control is a process implemented by the board of directors, as well as all employees under their direction with the aim of providing adequate guarantees for the achievement of control objectives. In general, internal control is part of each system used as procedures and operational guidelines for companies or organizations companies generally use an internal control system to direct company operations and prevent system misuse (ISSN1174 Emba Journal, A. Paul.)

The Committee of Sponsoring Organizations of the Treadway Commission (COSO) in 1992 issued a definition of internal control. The COSO definition of internal control is as follows: Internal control system is a process that involves the board of commissioners, management, and other personnel, which is designed to provide adequate confidence about achieving the following three objectives:

- Effectiveness and efficiency of operations

- Reliability of financial reporting

- Compliance with applicable laws and regulations.

In the latest edition, $\operatorname{COSO}$ (2013: 3) defines internal control as follows:

"Internal control is a process, effected by an entity's boar of directors, manage- ment, and other personnel, designed to provide reasonable assurance regarding the achievement of objectives relating to operations, reporting, and compliance. "

Understanding internal control according to the COSO, it can be understood that internal control is a process, because it penetrates the operational activities of the organization and is an internal part of basic management activities. Internal control can only provide adequate confidence, not absolute confidence. This confirms that no matter how well internal controls are designed and operated, they can only provide adequate confidence, and cannot be fully effective in achieving internal control objectives even though they have been designed and arranged in the best way possible. Even though the ideal internal control is well designed, but success depends on competition and the constraints of the implementation that is inseparable from various limitations.

\section{RESEARCH METHODS}


The method of writing this article is a descriptive qualitative method and library research, where the author obtained from modules, texts, or the internet, besides that based on empirical experience and direct research on research objects in traveloka companies.

\section{FINDINGS AND DISCUSSION}

Dependence on information systems in the modern era is something that is still felt by all circles. The use of technology for information systems began to be used by start-up companies, this proves that not only multi-national class companies or fairly large companies are implementing information systems. For example Traveloka, traveloka companies utilize Android-based smart phone technology or OS I-phone to serve in the service sector, namely travel, wherever and wherever information systems have been widely used by organizations or companies in providing services to customers or consumers. This information system is connected to a large network, namely the internet, making it easier for both the company and customers or consumers. With the internet the company is also helped in expanding its reach. In this modern era the position of computer technology is seen as important as a tool for automation of processes so that it becomes an essential factor in determining business strategies. combining computer-based management information systems with business strategies is a diamond step to get a competitive advantage from competitors.

However, behind the benefits, there are also problems that occur in this company both internally and externally, such problems are, recently, there have been cases where accounts from traveloka can be broken by parties who are not the account owners, which have an impact on user unrest, who are disadvantaged when opening a traveloka account and email notification of traveloka bills on paylater payment method transactions through the account carried out by unscrupulous persons, this is a criminal activity which is fraudulent behavior and has violated the law this can also occur due to accidental application or omission of an existing system which includes threats from the accounting information system.

This can happen where not the owner of a traveloka account can actually activate PayLater by entering another name and data of another person or false data and then misusing the account by using the paylater opportunity with the maximum limit to buy plane tickets or other after it appears the bill must paid by the original owner of the traveloka account itself automatically even though the account owner does not feel ordered or activate the PayLater.

This includes computer attacks, namely DNS Spoofing type spoofing. After the account owner is aware of and reports to traveloka and traced, this can occur mostly because the email address is connected to Google, this can be overcome by Sniffer by detecting the presence of smugglers in the network, cases this, initially the account owner actually will not realize this because traveloka is functioning properly but after the transaction has occurred suddenly there is an incoming bill via email that makes the account owner aware. This can happen also related to trojans by stealing the password of the account and using cookies stuffing by hijacking the traveloka account, also related to PHP Injection where the Hacker can make fake data and confirmed or trusted by the traveloka so that there is an abuse of the account that harms the real account owner itself. Security attacks also occur namely interception and modification and fabrication. This can also be dealt with by Traveloka to tighten security aspects of computers such as Athentication, Integrity, Non-repudiation, Authority, Confithentiality, Privacy, Availability and Access Control in order to minimize incidents like this.

In general, control is part of each system that is used as operational procedures and guidelines for a particular company or organization. Companies generally use internal controls to direct the company's operations and prevent system misuse. However, it must be stressed once again that no matter how well internal controls are designed and operated, they can only 
provide adequate confidence, cannot be fully effective in achieving internal control objectives even though they have been designed and arranged in the best way possible. Even though the ideal internal control is well designed, but success depends on competition and the constraints of the implementation that is inseparable from various limitations.

In its implementation too, many cases that occur in large traveloka companies are still not effective in carrying out internal control, this case occurs when there is a breakdown of the traveloka paylater system that still harms many people including me, how can the confidentiality of one's data be accessed and burglarized in such a way as to cause financial losses suffered by the victims concerned. Of course in this case the traveloka must be able to improve the components of internal control carried out, especially in terms of Risk Assessment and Control Activities.

At Traveloka company, ethics in the information society, the official traveloka account owner asks for protection of account ownership by blocking ovo paylater that has been misused by account breakers, in identifying company stakeholders providing solutions to change passwords and traveloka has blocked the paylater after that traveloka gives the view that the account can be broken into because the email used by authorized users of the account is connected by google, with the existence of the traveloka party suspected the possibility of being broken because of it. This incident is clearly detrimental to the official traveloka user himself, because the right to use the paylater cannot be reused due to being blocked by traveloka and the opportunity to use the paylater cannot be used.

The occurrence of paylater breakthroughs from irresponsible people, this shows that Traveloka has not fulfilled 7 COBIT criteria (Effectiveness, Confidentiality, Integrity, Availability, Compliance and Reliable) in its business field. Broadly speaking the Control Objective for Information and Related Technology (COBIT) at Traveloka has been implemented but, the results are not good, please note traveloka has been handled structurally in the System and Information Technology Division (DIVSI) headed by a Head of Division under the Directors, and supervised by the financial services authority (OJK) but this is still lacking because account burglary cases can still occur repeatedly.

For business risk management or Enterprise Risk Management (ERM), Traveloka forms a Division under the Board of Directors that handles risks faced by the company or that may arise in the company. This division conducts mapping, categorizing and making risk mitigation which is then evaluated and controlled continuously every month, quarterly, semester and yearly. However, although Traveloka has implemented this, the paylater incident according to the news, there are still many complaints the same thing.

\section{CONCLUSION AND SUGGESTION}

In the implementation of the rampant cases that occur in large companies including traveloka in carrying out internal control is still not effective, this case occurs when the traveloka paylater system pemboboaln that still harms many people including the author himself, where the confidentiality of one's data can be accessed and compromised in such a way that incur financial losses suffered by the victims concerned. Of course in this case the traveloka must be able to improve the components of internal control carried out, especially in terms of Risk Assessment and Control Activities.

In the case of cases like this need to be improved fraud detection, this can be minimized by tightening security to log in from mobile phones or other gadgets by improving existing systems and tightening supervision of internal controls of the traveloka company 
itself can help indicate fraud and minimize existing fraud, and improve the application of COBIT, COSO and ERM in traveloka companies so that burglary events can be minimized until they do not occur.

\section{REFERENCE}

Accounting Information for Internal Revenue Control. EMBA Journal - ISSN 2303-1174.

Information System and Internal Control Lecture Module 1-5 meetings by Prof. Dr. Ir. Hapzi Ali, MM, CMA

www.slideshare.net/mobile/MAYANIH1/sipi-mayanih-prof-hapzi-ali-sistem-informasiimplementasi-pada-pt-karya-baru-jaya-persada-universitas-mercu-buana-2018-pdf (Accessed 5 October 2019, 12:04)

mediakonsumen.com/2019/05/08/surat-pembaca/account-paylater-traveloka-dibobol-hackerkorban-tetap-dib Charge-billing (accessed 05 October 2019 at 09.41)

www.slideshare.net/HAJUINIZEIN/sipihajuinihafzi-ali-pendalian-internal-cosouniversitasmercu-buana2018pdf (Access 05 October 2019 At 09.45)

Steffi Sigilipu (2013) Effects of Application of Management Accounting Information and Systems Performance Measurement Against 1, No Managerial Performance. ejournal Unstrat Vol.3 No.1 